\title{
ANALYSIS OF GLUCOSE AND ZINC LEVEL IN SERUM AND BLOOD ON CONSUMPTION OF ZINC FORTIFIED DAHI
}

\author{
PRIYANKA ${ }^{1}$, NARASIMHA MURTHY ${ }^{2}$ \& RAJANNA. M $^{\mathbf{3}}$ \\ ${ }^{1,2}$ Department of Dairy Chemistry, Dairy Science College, Karnataka Veterinary Animal, India \\ ${ }^{3}$ Fisheries Sciences University (KVAFSU), Mahagaon Cross, Kalaburagi, India
}

\begin{abstract}
Food fortification is one of the approaches to prevent, and also correct a demonstrated deficiency of nutrient in the target populations. Milk and dairy products are frequently consumed by large population and are considered as, the ideal carriers in food fortification programs, which are taken major initiatives by Indian government in the recent trends of food industries. However, these products are found to be low in zinc level. Therefore, it is estimated that, fortification of these foods with a proper and appropriate zinc salt, it is an effective and economic strategy to prevent zinc deficiencies, which are found in new born and especially pregnant women. Many studies reveal the significance of Zinc in day-to-day life, to name a few, Zinc has active role in overcoming insulin resistance. It also, helps in the synthesis, storage and secretion of insulin. At this back drop, the present study attempted to find the infusion of zinc in milk and associated products, such as fortify with zinc by using @ $40 \mathrm{mg} / \mathrm{kg}$. The results conveys that, the standard levels used in the study was $40 \mathrm{mg} / \mathrm{kg}$ of milk, zinc sulphate showed satisfactory level of organoleptic, physico-chemical viz., acidity, total solids, fat and protein. Apart from human beings, it has positive impact also on animals, thus experimentation by feeding rats with micro-mineral fortified dahi revealed increased gain in body weight, Feed and Protein Efficiency Ratio values (FER \& PER). Blood serum zinc concentrations showed tremendous increase in rats, fed with fortified dahi than in animals fed with unfortified dahi, which was used as control for the study. Further, conversely, the study found that, lower blood glucose levels were observed in experimental animals, fed with fortified dahi than animals fed with control dahi. From the present study, it can be concluded that, the zinc fortified dahi doesn't cause, sharp fluctuations in blood glucose levels, rather stabilized the blood glucose levels and hence, the zinc fortified fermented milk products can safely be consumed by early diabetic people, to control blood glucose levels.
\end{abstract}

KEYWORDS: Dahi, Fortification, Insulin, Zinc, Blood Serum \& Protein Efficiency Ratio

Received: May 16, 2017; Accepted: Jun 14, 2017; Published: Jul 06, 2017; Paper Id.: IJAPBCRAUG20171

\section{INTRODUCTION}

Fermented milk products reportedly have therapeutic, anticholesterolemic, anticarcinogenic and anticariogenic properties beyond their basic nutritive value. Dahi, is the most important fermented milk product used in India from time immemorial. The popularity of dahi is not only due to its refreshing taste and palatability, but also due to its scientifically proven role as a nutritious fermented milk product. In Indian system of medicine (Ayurveda), dahi has been strongly recommended for curing ailments like dyspepsia, dysentery and other gastrointestinal disorders. This product, is also believed to improve appetite and vitality. Apart from this, among Micro-minerals, especially zinc plays a pivotal role, in various physiological processes. It is the most important mineral for body metabolism, part of many enzymes like retinal dehydrogenase and alkaline phosphatase (Samy, 2010). Zinc is an essential nutrient for health and very important for growth, normal functioning of immune system 
and other physiological processes. It is also a component of the hormone, insulin. Its deficiency, results in growth retardation, delayed wound healing and hypogonadism.

\section{MATERIALS AND METHODS}

The procedure for preparation of dahi by Khedkar et al (2014) was adopted with suitable modifications. Milk obtained from Student Experimental Dairy Plant (SEDP), of Karnataka Veterinary Animal and Fisheries Sciences University (KVAFSU), of Hebbal, Bengaluru-24. For standardization of cow milk (fat 3.5\% and SNF 8.5\%), Nandini cream and spray dried Nandini skim milk powder were used. The standardized milk was preheated to $60^{\circ} \mathrm{C}$ and homogenized (at $2500 \mathrm{psi}$ and $500 \mathrm{psi}$ ). Then, the milk was heated to $95^{\circ} \mathrm{C}$ for $15 \mathrm{~min}$. During heating, milk was stirred continuously with the help of stirrer to avoid formation of cream layer, cooled to $37^{\circ} \mathrm{C}$, and divided into two equal portions: The first portion served as control and the second portion was fortified separately with zinc sulphate (Food grade: Merck Chemicals. Germany), at a level of 20, 30 and 40mg zinc/ kg milk. Milk was inoculated with desirable proportion of starter culture (Streptococcus lactis, streptococcus diacetylactis, along with the species of Lactobacillus, such as Lactobacillus bulgaricus and Streptococcus thermophillus, in the ratio of 1:1), at the level of 1\%. Milk, along with culture added was filled into clean polystyrene cups. The samples were incubated at $30 \pm 1^{\circ} \mathrm{C}$, until curd formation/coagulation (17hr). Thus, the obtained dahi samples were stored at $5 \pm 1^{\circ} \mathrm{C}$, until they were used for experiments.

$\mathrm{pH}$ of the sample was measured using a digital $\mathrm{pH}$ meter (Chemi line Pvt. Ltd.) at $25^{\circ} \mathrm{C}$. Acidity, protein, fat, total solids, ash and moisture content of dahi was estimated as per the standard procedure IS: SP 18 (Part XI) 1981. MSNF content in milk was computed by using ISI Lactometer, by using the following formula

\section{SNF $(\%)=0.25$ CLR+0.2F+0.35}

Where,

\section{CLR-Corrected Lactometer Reading}

F-Fat (content in per cent)

Prepared dahi samples were given to a panel of five judges, for sensory evaluation. Each judge was supplied with a standard score card of a total of 25 points, for assessing the degree of firmness, whey separation, texture and flavour.

A total of 18 adult male albino rats weighing about 100-110 g, were used in the experiment. Animals were kept under normal laboratory conditions, for 1 week before the initiation of the experiment. Rats were allowed free access of water and were fed on uniform diet. Six rats served as a normal control, another six rats subjected to the dahi (without treatment with mineral) and other six rats were subjected to the fortification with mineral treatment. Fortified dahi similarly along with control sample transformed into pellets, and those pellets were fed to experimental animals (Dhar, 1959).

For blood collection, overnight fasted rats were first anesthetized by exposing them to ether vapour, in a glass jar, for a brief period of time. On $28^{\text {th }}$ day, blood was collected from experimental animals in clean, sterilized and labelled test tubes, by retro-orbital plexus puncture method, using microhaematocrit capillary tubes. Blood glucose levels were measured immediately after the blood collection by using Glucochek glucometer (Aspen diagnostic (P) Ltd. Delhi, India). Immediately after the collection of blood, the tubes were held in a slanting position to facilitate serum separation at room temperature for 1-2 hrs, then centrifuged at $2000 \mathrm{rpm}$ for $10 \mathrm{~min}$, and the clear nonhaemolysed serum was then transferred into a clean, sterilized vial. The separated serum was used for analysis of minerals. Zinc in blood serum was estimated in 
Erba Versatile Biochemical Analyzer, using commercially available, ready to use kits (Lab-Care Diagnostics). The protein efficiency ratio (PER) of both control and experimental diets fed rat, were determined as per the procedure of IS: 7481 (1974). The food value and growth rate as effected by food intake, was determined as feed efficiency ratio (FER) and expressed as gain in weight, in grams per unit of food consumed. The results (average of 3 trials) were analyzed using SPSS software package Version10.0, to assess the test of significance, using ANOVA and MS Excel 2007.

\section{RESULTS AND DISCUSSIONS}

\section{Influence of Different Levels of Zinc on Sensory Attributes of Dahi}

Ideally, Dahi should possess, a pleasant and clean acid flavor. It should be free from undesirable flavors, such as: bitter, rancid, oxidized, stale, yeasty and unclean. The best results for flavor, were obtained from zinc fortification at 40 $\mathrm{mg} / \mathrm{kg}$ level presented in the table 1 . When zinc fortified dahi, at $20,30 \mathrm{mg} / \mathrm{kg}$ was subjected for sensory evaluation, they have scored less points, because of whey separation and high degree of souring. Higher fortification ( $>40 \mathrm{mg} / \mathrm{kg}$ ), yielded dahi with metallic flavour. Hence, for the experimental studies, an optimum level of $40 \mathrm{mg}$ of zinc/kg is employed, and can be used in large for developmental health improvements in all food and allied sectors. The study was also focused to know the appearance of dahi with fortification with Zinc, the findings revealed that, the appearance for the highest score was obtained for dahi fortified zinc at $40 \mathrm{mg} / \mathrm{kg}$, when compared with zinc fortified at $20 \mathrm{and} 30 \mathrm{mg} / \mathrm{kg}$. These findings were in agreement with those given by El-kholy (2011) and El-Din et al. (2012). Natural dahi shall posses a firm, custard- like body with a smooth homogeneous texture. The best results, for body and texture was observed in dahi fortified with zinc at $40 \mathrm{mg} / \mathrm{kg}$ level. Scores were low for dahi fortified with zinc, at 20 and $30 \mathrm{mg} / \mathrm{kg}$ level. This is due to the whey separation in samples.

\section{Effect of Different Levels of Zinc Fortification on Physico-Chemical Properties of Dahi}

The findings convey that, Unfortified dahi showed quality parameters such as $\mathrm{pH}$, acidity, total solids, fat, SNF, protein contents as 4.4, 0.76 percent and lactic acid, 11.77, 3.2, 8.57 and 3.4 percent respectively. Fortification of dahi with zinc salts, at the rate of 20,30 and $40 \mathrm{mg} / \mathrm{kg}$ had no noticeable effect on physio-chemical properties, such as pH, acidity, total solids, fat, SNF and protein, i.e., it remained almost similar, when compared to unfortified dahi.

Table 1: Effect of different Levels of Zinc on Sensory Attributes of Dahi

\begin{tabular}{|c|c|c|c|c|c|c|}
\hline \multirow[b]{2}{*}{$\begin{array}{c}\text { Level of Zinc } \\
\text { (mg Zinc/kg Milk) }\end{array}$} & \multicolumn{6}{|c|}{ Sensory Attributes (Max. Score: 25.00) } \\
\hline & $\begin{array}{l}\text { Flavour } \\
\text { (10) }\end{array}$ & $\begin{array}{l}\text { Sourness } \\
\text { (2) }\end{array}$ & $\begin{array}{c}\text { Appearance } \\
\text { (5) }\end{array}$ & $\begin{array}{c}\text { Body \& } \\
\text { Texture } \\
\text { (5) }\end{array}$ & $\begin{array}{c}\text { Closure \& } \\
\text { Container } \\
\text { (3) }\end{array}$ & $\begin{array}{c}\text { Total } \\
\text { (25) }\end{array}$ \\
\hline Control & 8.08 & 1.66 & 4.33 & 4.46 & 2.81 & 21.34 \\
\hline 20 & 8.16 & 1.58 & 4.41 & 4.08 & 2.83 & 21.06 \\
\hline 30 & 8.50 & 1.63 & 4.33 & 4.16 & 2.82 & 21.44 \\
\hline 40 & 8.50 & 1.75 & 4.66 & 4.50 & 2.84 & 22.25 \\
\hline $\mathrm{CD}(\mathrm{p} \leq \mathbf{0 . 0 5})$ & 0.86 & 0.47 & 0.77 & 0.64 & 0.01 & 1.80 \\
\hline
\end{tabular}

All values are average of three trials

*Scores graded based on 25-point hedonic scale.

Influence of Zinc on Blood Serum Zinc Concentration and on Blood Glucose Level in Rats Fed with Experimental Diet

The findings reveals that, the serum zinc concentration was monitored to understand the effect of zinc fortification 
in dahi, which was presented in the Table 2. It also showed that, Serum zinc concentration was high in rats, which were fed with dahi fortified with zinc $(288.50 \mathrm{mg} / \mathrm{dl})$, when compared to serum zinc concentration of animals fed with control (221.0 $\mathrm{mg} / \mathrm{dl})$ and unfortified dahi (254.33). This could be attributed to binding of zinc, which is a cation by Caseinophosphopeptides (CPPs), derived from the enzymatic modifications of proteins in dahi, as also during gastrointestinal digestion, in experimental animals, thus, they are more bio-available.

Table 2: Effect of Zinc on Blood Serum zinc Concentration and on Blood Glucose Level in Rats Fed with Experimental Diet

\begin{tabular}{|l|c|c|}
\hline Type of Diet & $\begin{array}{c}\text { Serum Zinc } \\
(\mathbf{m g} / \mathbf{d l})\end{array}$ & $\begin{array}{c}\text { Blood Glucose Level } \\
\text { (mg/dl) }\end{array}$ \\
\hline Control & 221.00 & 92.0 \\
\hline D1 & 245.33 & 87.5 \\
\hline D2 & 288.50 & 82.5 \\
\hline
\end{tabular}

All values were average of six trials at the end of $4^{\text {th }}$ week of feeding period.

Control D1: Unfortified dahi D2: Dahi fortified with zinc (40 mg/kg)

Further, the study also attempted to assess the blood glucose levels in animals, the findings revealed that, lowest blood glucose level $(82.5 \mathrm{mg} / \mathrm{dl})$ was observed in experimental animals, fed with zinc fortified $(40 \mathrm{mg} / \mathrm{kg}) \mathrm{dahi} \mathrm{sample}$ when compared to blood glucose level of animals fed with control (92 mg/dl), unfortified dahi (87.5 mg/dl), indicating that, the zinc in fortified dahi plays a vital role in stimulating insulin formation, thus, such fortified dahi is an ideal food for early diabetics. Because, zinc plays physiological role in synthesis, storage and secretion of insulin, and it seems to stimulate insulin action and insulin receptor tyrosine kinase activity. Adequate zinc in the body plays at least three roles, with respect to glucose utilization, involving a hormone. First, zinc binds to insulin, so that insulin is adequately stored in the pancreas and released when glucose enters the blood stream. Second, zinc improves cell health, making up a component of the enzymes necessary for insulin to bind to cells, so that glucose can enter, and be used as fuel. The process of insulin binding to the cell is what is referred to with the term "insulin sensitivity", and means that, the cell is receptive to insulin. Once the insulin binds to the cell, it "opens the door" so that the glucose can enter into the cell. Finally zinc is important for preventing insulin resistance, as a high zinc level seems to be connected with decreased insulin resistance. Higher levels may affect the ability of the islet cells of the pancreas to store insulin; zinc appears to have a protective effect against the destruction of the $\beta$-cells of pancreas (Ranasinghe et al., 2013). Which are the production sites for a hormone. The presence of Zinc levels, minimizes the variations in blood glucose levels, by the effect of decreased glycemic load, this effectively mitigates the harmful effects of diabetes patients, which now-a-days has been increasing more steeper than previous years, in the young and old populations, especially in a country like India. Thus, this effect is responsible for controlling, type 1 and type 2 diabetes. Many of the enzyme systems, in which zinc is a necessity for, are involved with the metabolism of blood sugar, and therefore, zinc has been used as natural catalyst for insulin secretion enzyme mechanism. The $\beta$-cells that secrete insulin in pancreas, are also highly stored with zinc (Jayawardena et al., 2012). From these discussions, it is much clear that the dahi fortified with zinc, can safely be used in persons with early diabetic mellitus, which will be a boon for tackling the fast growing disease on a huge population, within a short time. 


\section{CONCLUSIONS}

The above findings help to conclude the study in the following ways. The Dahi made by using $1 \%$ starter culture showed uniform body and texture, optimum acidity with no whey separation. The increase in starter culture level resulted in increased acidity reflecting, increased sourness. Hence, dahi made by using $1 \%$ starter culture was used for experimental studies. The sensory score revealed that, possibility of making good quality dahi, by fortifying milk with food grade zinc sulphate and, dahi made from such fortified milk respectively, at a level of $40 \mathrm{mg} / \mathrm{kg}$ milk, the resultant dahi was not different from, the control upon organoleptic properties. Apart from these findings, it has also revealed that, this level of fortification of the dahi samples, exhibited metallic flavour. Hence, dahi fortified with zinc sulphate at an optimum level of $40 \mathrm{mg} / \mathrm{kg}$ is employed for the study. Fortification of dahi with zinc salts at this rate had no noticeable effect on physicochemical properties. The influence of fortified zinc in dahi was administered to rats, and the blood serum zinc concentration was monitored. Serum zinc concentration, was significantly higher in dahi fortified with zinc, when compared to control and unfortified dahi. Zinc, is important to prevent the disorders which occur due to deficiency of zinc. Thus, from the results, it can be concluded that, fortified zinc is the best choice for fortification in dahi, and in infant food formulations, to overcome the deficiencies for micro mineral related disorders, in infants and growing children.

The effect of fortified zinc in dahi on blood glucose level, in rats was measured. Zinc reduces the glycemic load in blood, thus sharp fluctuations in blood glucose levels are not seen. This is due to the fact that, zinc plays a key role in the synthesis, storage and secretion of insulin, and it seems to stimulate insulin action and insulin receptor tyrosine kinase activity. Zinc plays an important role in overcoming insulin resistance. Thus, zinc in fortified dahi stabilizes blood glucose levels, as a result, such zinc fortified fermented milk products can safely be consumed by early diabetic people.

\section{REFERENCES}

1. DHAR, D. C., 1959. Preparation of balanced stock diet for laboratory animals (rats and mice). J. Sci. Industr. Res.180: 250252.

2. El-DIN, G, A. M., HASSAN, A. S. H., EI-BEHAIRY, S. A. and MOHAMED, E. A., 2012. Impact of zinc and iron salts fortification of buffalo's milk in the dairy product. World. J. Dairy. Food. Sci.7: 21-27.

3. El-KHOLY, A. M., OSMAN, M., GOUDA, A. and GHAREEB, W. A., 2011. Fortification of yoghurt with iron. World. J. Dairy. Food. Sci. 6: 159-165.

4. HOSSAIN, M., FAKRUDDIN, M and ISLAM, N. M., 2012. Development of Fruit Dahi (Yoghurt) Fortified with Strawberry, Orange and Grapes Juic Am. J. Food Technol., 7(9):562-570.

5. IS: SP: 18, 1981, ISI Handbook of Food Analysis, Part XI, Dairy products. Indian Standards Institution, Manak Bhavan, New Delhi, India.p: 173.

6. IS: SP: 7481, 1974, ISI Handbook of Food Analysis, Part XI, Dairy products. Indian Standards Institution, Manak Bhavan, New Delhi, India.p: 122-124.

7. JAYAWARDENA, R., RANASINGHE, P., GALAPPATTHY, P., MALAKANTHI, R. L. D. K., CONSTANTINE, G. R. and KUTULANDA, P., 2012. Effect of zinc supplementation on diabetes mellitus: a systematic review and meta-analysis. Diabetology. Metabolic. 4: 13.

8. KALE, A.K., DHANALAKSHMI, B and KUMAR, U., 2011. Development of Value Added Dahi by Incorporating Cereal and Fruits. J. Food Sci. and Engineering., 1: 379-385. 
9. KHEDKAR, C. D., KHEDKAR, G. D., KALYANKAR, S. D., BAJAD, D. N. and SARODE, A. R., 2003. Dahi. Encyclopedia of food sciences and nutrition, second edition. Academic press. 3: 1721-1725.

10. RANASINGHE, P., JAYAWARDENA, R., PIGERA, A., KATULANDA, P., CONSTANTINE, G, R. and GALAPPATTHY, P., 2013. Zinc supplementation in pre-diabetes: Study protocol for a randomized controlled trial. Sri Lanka. Clin. Trial.14: 52.

11. SAMY, A., EI-BEHAIRY. and EZZAT A. M, 2010. Properties of yoghurt made from fortified buffalo's milk with iron and zinc Salts. World J. Dairy Food. Sci. 5: 207-213. 